\title{
ANALYSIS OF MULTIDIMENSIONAL POVERTY IN RURAL ADAMAWA STATE, NIGERIA
}

\author{
Amurtiya Michael ${ }^{1 凶}$, Abdu Karniliyus Tashikalma ${ }^{1}$, David Chinda Maurice ${ }^{1}$, \\ Ahmadu Abubakar Tafida ${ }^{1}$ \\ ${ }^{1}$ Modibbo Adama University of Technology, Nigeria
}

\begin{abstract}
This study assessed multidimensional poverty in rural parts of Adamawa State, Nigeria. Specifically, the study objectives were to: describe the respondents' socio-demographic characteristics, determine their multidimensional poverty status, and identify the determinants of multidimensional poverty in the communities sampled. A multi-stage cluster sampling technique was used to collect primary data from 480 household heads selected from 16 villages across the study area. Data collected was analyzed using descriptive statistics, the Multidimensional Poverty Analytical Tool (MPAT) and a binary logistic regression model. The respondents' sociodemographic characteristics described in the study showed that their mean age was 46.3 years while the average household size was 7 persons. The study indicated that the majority $(86.7 \%)$ of respondents were male, mostly married $(91.7 \%)$ and educated (74\%). The distribution of the respondents' multidimensional poverty status revealed that majority $(61.7 \%)$ of the households were poor. The study revealed that multidimensional poverty in the study area is influenced negatively by age, marital status and household size. Similarly, gender, educational level, livelihood activities, farm size, livestock ownership, remittance, membership of group, and access to credit have a positive effect on multidimensional poverty. Key among the recommendations of this study is the provision of adequate basic infrastructure in the area.
\end{abstract}

Keywords: multidimensional poverty, rural, Adamawa State, Nigeria

\section{INTRODUCTION}

Poverty is a negative state that threatens life, and considering its global prevalence, it is regarded as the foremost developmental challenge of many countries across the globe over the years (Jana et al., 2012; Ologbon et al., 2014; Sokołowski et al., 2019). Poverty connotes deprivation of, or insufficient access to, resources below certain acceptable standard in the society. According to Kanasz (2017), poverty occurs as a result of an unfortunate coincidence of external factors. To Tollens (2002), poverty is not an intrinsic attribute of people, but a product of livelihood systems. Similarly, Mitchell et al. (2008) considered poverty to be the failure of an individual to create and sustain a viable livelihood.

Traditionally, poverty was considered a monetary issue, and hence, income was used as proxy for measuring it (Luczka-Bakuła and Kalinowski, 2006; Adeoti, 2014). In recent past, the concepts of poverty have been broadened to include many other human development variables that are not necessarily economic in nature (Battiston et al., 2009; Le, 2015). Poverty is now viewed as a multidimensional and extremely complex problem, depending on the context, place or capacity to deal with it (Kalinowski, 2018). Various typologies of material deprivation now exist in the literature, including in the context of cross-country analyses (Anacka and Kobus, 2011; Bieńkuńska, 2013; Sokołowski et al., 2019). This multidimensional conceptualization of poverty takes

$\bowtie$ Amurtiya Michael, MSc, Department of Agricultural Economics and Extension, Modibbo Adama University of Technology, Yola,
P.M.B. 2076, Yola, Adamawa State, Nigeria, e-mail: michaelamurtiya@yahoo.com, https://orcid.org/0000-0001-5273-9999 
into cognizance human development variables like access to public goods (e.g. education, healthcare, potable drinking water, sanitation etc.) and adequacy of social capital (absence of social exclusion). It is expected that such a multidimensional view of poverty will provide a comprehensive measurement of poverty, leading to the formulation and implementation of improved poverty reduction policies (Ologbon et al., 2014; Le, 2015). However, it is important to note that multidimensional poverty measurement should not be mistaken to be a simple measure of poverty along different dimensions considered separately, since then, upon aggregation, the association between attributes will be washed out. Association is a distinctive feature of multidimensional analysis; in fact, it is association that makes the analysis truly multidimensional (Anacka and Kobus, 2011; Yang and Vizard, 2017).

Eradicating the multiple dimensions of poverty is the foremost priority of the United Nations' Sustainable Development Goals (SDGs). The prominence of poverty eradication in the agenda of the United Nations is due to the global high prevalence of various dimensions of poverty across countries regardless of their level of development. While poverty is extremely severe in developing nations, especially those in Africa and Asia, developed nations in Europe still feel the scourge of poverty among some of its citizens (Bene and Friend, 2009; Abur et al., 2013; Kalinowski, 2018). In Nigeria, poverty is deep and widespread (Aderonmu, 2010), and its distribution in the country has shown a very high incidence in rural areas where bulk of the nation's population reside (Adepoju and Yusuf, 2012; NBS, 2017). The country's rural space holds about $53 \%$ of the nation's population (USAID, 2015). Rural livelihoods in Nigeria are mostly hinged on agriculture and other non-farm activities that depend on natural resources and are abundant in the localities (NBS, 2017). However, rural livelihoods are usually vulnerable to climate-related shocks and other economic risks and stresses (Mitchell et al., 2008). Similarly, most rural areas have limited incomegenerating opportunities and access to infrastructure and services (Mitchell et al., 2008; Aderonmu, 2010). The interplay of these factors has perpetuated the prevalence of poverty in most rural contexts.

Poverty in rural Nigeria is multifaceted and has increased geometrically in the last three decades (Abur et al., 2013). Currently, the country has the highest (over 90 million) proportion of persons living in extreme poverty (World Poverty Clock, 2018). In fact, according to the organization, about 14 persons slide into such poverty every minute in the country. In terms of multidimensional poverty, Nigeria is still home to about 97 million poor people which is more than any other subSaharan African country (OPHI, 2018). The scale and complexity of poverty in Nigeria differs with location (Ifelunini et al., 2013). For instance, the North-East subregion has a very high incidence of both income and multidimensional poverty (NBS, 2017; OPHI, 2017). A critical look at the incidence of multidimensional poverty in Adamawa State indicated that the State has $59 \%$ of its populace multidimensionally poor while an additional $20.4 \%$ live near multidimensional poverty (are vulnerable). Similarly, in terms of human development, the State's score of 0.428 has fallen short of the national average score of 0.511 (UNDP, 2018). In rural parts of the State where bulk of the population reside and practice farming as their primary livelihood activity (Adamawa..., 2016), the scale of such poverty and low human development could be much higher.

Across rural areas of Nigeria, the multidimensional deprivation (poverty) of human wellbeing is expressed in many ways. These deprivations are evident in terms of rural communities' limited access to basic social amenities/services (especially healthcare, education, potable drinking water, electricity, good access road etc.), food insecurity, inadequate financial resources, degraded environment, and social exclusion from civil, social and cultural life. However, a more worrisome consequence of poverty in recent past in Nigeria - apart from the glaring underdevelopment in most rural areas - is the issue of insecurity which has caused instability in most parts of the country (Muhammad, 2012; Egwemi and Odo, 2013). A case in point to this assertion is the challenge of Boko Haram insurgency affecting most parts of the North-East (especially, Borno, Yobe, and Adamawa States). Over the years, these problems have contributed substantially in causing civil unrest leading to largescale humanitarian crisis, underdevelopment and loss of livelihoods for most residents of the region (Ogbozor, 2016; UNDP, 2018).

In a bid to eradicate poverty and promote rural development in the country, several developmental programs and projects were initiated and implemented by the government at every tier over the years. However, despite the adoption of a wide range of poverty reduction strategies over the years by the government, 
poverty is still pervasive in most parts of the country. According to Adepoju and Yusuf (2012) and Agbaje et al. (2013), improper diagnosis of poverty is advanced prominently among the reasons for the country's inability to eradicate poverty over the years. This has caused poor targeting of interventions' beneficiaries resulting in lack of policy continuity (Onwuemele, 2015). Similarly, the issue of poverty in Adamawa State has elicited several studies in recent years (Margwa et al., 2015; Tashikalma et al., 2016). However, in contrast to the multidimensional nature of the problem, most of these attempts considered the problem from a unidimensional angle (used income/ expenditure as an indicator of poverty); whereas others only covered parts of the State. Having an understanding of the multidimensional nature of rural poverty (especially the pattern and determinants) is a necessity for effective pro-poor development strategies that will reduce poverty and improve people's wellbeing (Ifelunini et al., 2013). To effectively address poverty and minimize deprivation (and improve well-being), there is the need to understand the prominent underlying causes of poverty and reduce it across all fronts (Ologbon et al., 2014; Dudek and Lisicka, 2015). Hence, there is need for a more detailed multi-dimensional analysis of the problem in the State. The specific objectives of the study were to describe the socio-demographic characteristics of the respondents sampled, determine the multidimensional poverty status of the respondents, and identify the determinants of multidimensional poverty in the area.

\section{Study area}

Adamawa State is located in north-east Nigeria, between latitudes $7^{\circ}$ and $11^{\circ} \mathrm{N}$ and between longitudes $11^{\circ}$ and $14^{\circ} \mathrm{E}$ (Adamawa..., 2016). The State covers a landmass of about $38,700 \mathrm{~km}^{2}$, and experiences a tropical wet and dry climate. During the wet season, the mean annual rainfall ranges from $197 \mathrm{~mm}$ to $700 \mathrm{~mm}$ in the southern and north-western parts of the State, respectively. The State has an estimated population of about $4,438,628$ people who mostly reside in rural areas, and are mostly engaged in agricultural activities.

\section{Sampling technique}

The study used a multi-stage cluster sampling technique to draw respondents. In the first stage, nine Local Government Areas (representing 43\% of all LGAs in the State) were randomly selected. According to IFAD (2014), the Multidimensional Poverty Assessment Tool (MPAT) uses a standardized sample size of 16 to 30 villages with 30 households per village. The study adopted a 16 by 30 MPAT model, hence, 16 rural communities were randomly selected across the sampled Local Government Areas in the second stage. In the third stage, 30 households were selected at random from each of the villages sampled. Thus, 480 rural household heads were picked for the study. The villages sampled were Yadim, Muninga, Fa'a Gaya, Uding, Bole II, Gurumpawo, Sugu, Tsohon-Banjiram, Nasarawo Binyeri, Tola, Mbullo, Yanga, Karazah, Futuless, Bwade, and Pakka.

\section{Analytical technique}

The study used a combination of analytical tools to achieve its objectives. Descriptive statistics involving frequencies, means and percentages were used to describe the respondents' socio-demographic characteristics. The Multidimensional Poverty Analytical Tool (MPAT), as adopted from IFAD (2014), was used to determine the respondents' multidimensional poverty status. The determinants of multidimensional poverty were identified using binary logistic regression model in the study area. The Multidimensional Poverty Analytical Tool uses meticulously designed and established surveys to collect data on all the indicators of human wellbeing (Cohen, 2009; IFAD, 2014). Each subcomponent is made up of numerous survey items, and the values that constitute each subcomponent are aggregated using a weighted arithmetic mean and converted to a scale of 10-100. Afterwards, household scores were obtained for each subcomponent. Households with cumulative average scores below the cut-off point $(30 \%$ of the weighted indicators) were considered to be poor. The weighted arithmetic average formula as used by IFAD (2014) is presented as follows:

$$
y_{i j}=\sum_{i=1}^{n} w_{i k} x_{i j k}
$$

where: $y_{j k}$ is the score for household $j$ in subcomponent $k, w_{i k}$ is the weight attached to the survey question I in subcomponent $k$, and $x_{i j k}$ is the scaled score for household in question $i$ in subcomponent $\mathrm{k}$.

Therefore, $\sum_{i=1} w_{i k}=1$ and $0 \leq w_{i k} \leq 1$. 
These subcomponent scores were then aggregated using a weighted geometric average to calculate the main component scores. The weighted geometric average formula is as follows:

$$
y_{j k}=\prod_{i=1}^{n} x_{i j k}^{w_{i k}}
$$

where: $\mathrm{y}_{\mathrm{jk}}$ is the score for household $j$ in subcomponent $k, w_{i k}$ is the weight attached to the survey question I in subcomponent $k$, and $x_{i j k}$ is the scaled score for household in question $i$ in subcomponent $\mathrm{k}$.

$$
\text { Therefore, } \sum_{i=1} w_{i k}=1 \text { and } 0 \leq w_{i k} \leq 1 \text {. }
$$

The Multidimensional Poverty Status (MPS) of the respondents (which is bivariate), assumed the value of 1 for a multidimensionally non-poor household and 0 for a poor household. The binary logit regression model is expressed mathematically as:

$$
Y=\beta_{0}+\beta_{1} X_{1}+\beta_{2} X_{2}+\beta_{3} X_{3} \ldots \ldots \ldots \ldots . . .+\beta_{11} X_{11}+U
$$

where:

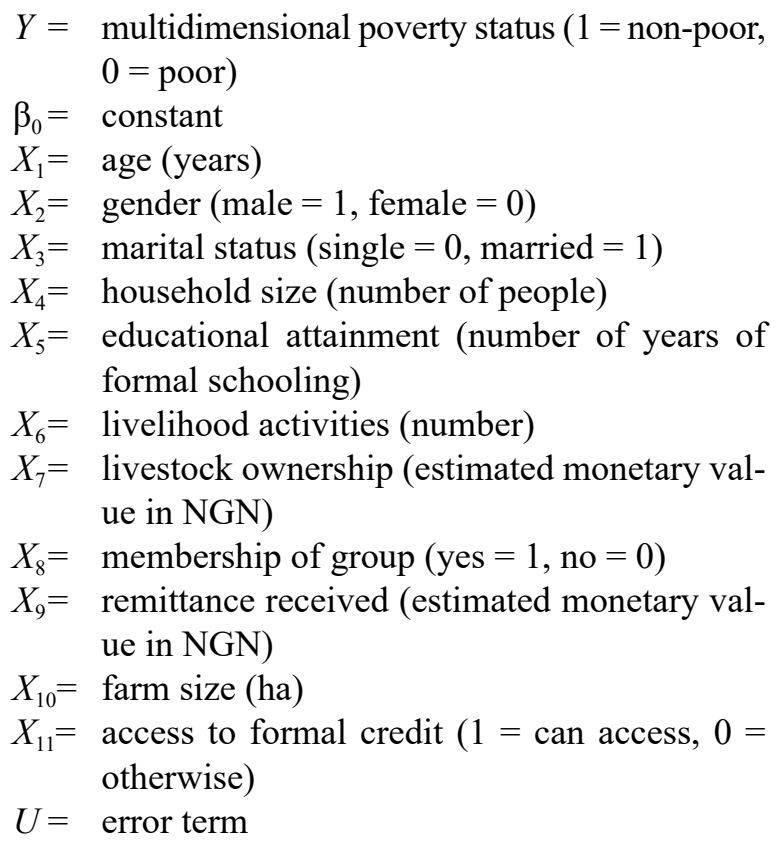

\section{RESULTS AND DISCUSSION}

\section{Socio-demographic characteristics of the respondents}

The socio-demographic characteristics of the respond-

\begin{tabular}{|c|c|c|}
\hline Variable & Frequency & Percentage $(\%)$ \\
\hline \multicolumn{3}{|l|}{ Age } \\
\hline$<30$ & 14 & 2.9 \\
\hline $30-39$ & 113 & 23.5 \\
\hline $40-49$ & 167 & 34.8 \\
\hline $50-59$ & 123 & 25.6 \\
\hline 60 and above & 63 & 13.1 \\
\hline
\end{tabular}
ents are presented in Table 1. Findings of the study
Table 1. Socio-demographic characteristics of the respondents

Mean 46.3

\begin{tabular}{lrr}
\hline Gender & & \\
Female & 64 & 13.3 \\
Male & 416 & 86.7 \\
\hline Marital Status & & \\
Married & 440 & 91.7 \\
Single & 12 & 2.5 \\
Divorced & 7 & 1.5 \\
Widowed & 21 & 4.4 \\
\hline Household Size & & \\
$1-5$ & 336 & 18.1 \\
6-10 & 56 & 70.0 \\
$11-15$ & 1 & 11.7 \\
$>15$ & & 0.2 \\
Mean 7 & & \\
\hline Educational Level & & \\
Non-Formal & 126 & 26.3 \\
Primary & 227 & 47.3 \\
Secondary & & 19.0 \\
Tertiary & & \\
Total & & \\
\hline
\end{tabular}

Source: field survey, 2018.

indicated that most of the respondents are relatively young (with an average age of 46 years). This implies that most of them can afford to engage in various livelihood activities that will contribute towards improved household wellbeing. The distribution of respondents by gender reveals that $86.7 \%$ of them were male while 
females constituted $13.3 \%$. The respondents' marital status revealed that married persons accounted for $91.7 \%$ while the singles, divorced and widowed constituted $2.5 \%, 1.5 \%$ and $4.4 \%$, respectively. Findings of this study showed that most households are large (with an average of 7 persons). The Table also presented the respondents' educational attainments which show that people with formal education constituted $73.7 \%$ while those with non-formal education accounted for $26.3 \%$.

\section{Sampled households' multidimensional deprivations}

Rural poverty has different manifestations as illustrated in Table 2. The findings indicated high deprivation in three fundamental human need components, namely housing, clothing and energy, education, and health. Similarly, there was high deprivation in terms of exposure and resilience to shock, which is a non-fundamental component. The highest deprivation was in terms of housing and clothing with an average score of $25.7 \%$.
This finding implies that most respondents live in houses that were constructed with substandard materials, and also have inadequate clothing materials to meet the expected standard. According to Sokołowski et al. (2019), energy poverty occurs when a household is unable to afford the energy needed to provide its members with adequate warmth, cooling, lighting, and appliance use. Households in the area mostly use unsustainable fuel source for cooking, heating and lighting. The study further revealed a very high level of educational deprivation (an average score of $30.1 \%$ ). This may aggravate the poverty situation of the people, as suggested by Holmes et al., 2012. Findings from this study also showed high deprivation in terms of health and healthcare, with an average score of $30.5 \%$. On the overall, health quality in the area is low, which was reflected in the low health status of the respondents and the inability of most of them to afford health services. This can frequently cause food and livelihood insecurity, and perpetuate vulnerability (UNDP, 2018). Another component with

Table 2. Component scores of Multidimensional Poverty Indicators

\begin{tabular}{|c|c|c|c|c|}
\hline \multicolumn{2}{|c|}{ Main and sub-components } & \multirow{2}{*}{$\begin{array}{c}\text { Average } \\
2\end{array}$} & \multirow{2}{*}{$\begin{array}{c}{[\min , \max ]} \\
3\end{array}$} & \multirow{2}{*}{$\begin{array}{c}\text { Average scores } \\
\text { of the main } \\
\text { components }\end{array}$} \\
\hline & 1 & & & \\
\hline \multirow[t]{3}{*}{ Food \& nutrition security } & consumption & 83.7 & {$[66.0,96.0]$} & 79.1 \\
\hline & access stability & 89.3 & {$[59.0,100.0]$} & \\
\hline & nutrition quality & 62.4 & {$[43.0,67.3]$} & \\
\hline \multirow[t]{3}{*}{ Domestic water supply } & quality & 52.9 & {$[42.8,60.0]$} & 65.5 \\
\hline & availability & 80.7 & {$[38.0,86.5]$} & \\
\hline & access & 62.8 & {$[51.0,72.0]$} & \\
\hline \multirow[t]{3}{*}{ Health \& health care } & health status & 44.1 & {$[31.0,55.0]$} & 30.5 \\
\hline & access \& affordability & 12.5 & {$[10.0,61.5]$} & \\
\hline & quality & 61.0 & {$[44.0,64.3]$} & \\
\hline \multirow[t]{3}{*}{ Sanitation \& hygiene } & toilet facility & 80.1 & {$[46.0,82.0]$} & 67.9 \\
\hline & household waste management & 45.7 & {$[25.0,53.5]$} & \\
\hline & hygiene practices & 76.2 & {$[67.5,78.0]$} & \\
\hline \multirow[t]{3}{*}{ Housing, clothing \& energy } & housing structure quality & 29.1 & {$[24.0,73.0]$} & 25.7 \\
\hline & clothing & 34.6 & {$[10.0,55.0]$} & \\
\hline & energy & 20.0 & {$[20.0,20.0]$} & \\
\hline
\end{tabular}


Table 2 - cont.

\begin{tabular}{|c|c|c|c|c|}
\hline & 1 & 2 & 3 & 4 \\
\hline \multirow[t]{3}{*}{ Education } & quality & 41.0 & {$[39.8,43.8]$} & \multirow[t]{3}{*}{30.1} \\
\hline & availability & 25.0 & {$[25.0,25.0]$} & \\
\hline & access & 32.4 & {$[10.0,65.0]$} & \\
\hline \multirow[t]{4}{*}{ Farm assets } & land tenure & 87.3 & {$[52.5,100.0]$} & \multirow[t]{4}{*}{44.0} \\
\hline & land quality & 75.0 & {$[50.0,100.0]$} & \\
\hline & crop inputs & 27.6 & {$[27.7,27.7]$} & \\
\hline & livestock/aquaculture inputs & 10.6 & {$[10.0,50.0]$} & \\
\hline \multirow[t]{3}{*}{ Non-farm assets } & employment \& skills & 38.0 & {$[21.3,73.8]$} & \multirow[t]{3}{*}{46.6} \\
\hline & financial services & 46.2 & {$[20.0,60.0]$} & \\
\hline & fixed assets \& remittances & 65.9 & {$[22.0,86.0]$} & \\
\hline \multirow{3}{*}{$\begin{array}{l}\text { Exposure \& resilience to } \\
\text { shocks }\end{array}$} & degree of exposure & 10.0 & {$[10.0,10.0]$} & \multirow[t]{3}{*}{35.8} \\
\hline & coping ability & 74.9 & {$[71.5,76.0]$} & \\
\hline & recovery ability & 60.4 & {$[41.0,67.3]$} & \\
\hline \multirow[t]{3}{*}{ Gender \& social equality } & access to education & 82.1 & {$[70.0,94.0]$} & \multirow[t]{3}{*}{57.0} \\
\hline & access to health care & 55.0 & {$[55.0,55.0]$} & \\
\hline & social equality & 42.8 & {$[19.6,82.5]$} & \\
\hline
\end{tabular}

Source: MPAT result output, 2018.

high deprivation is the respondents' exposure and resilience to shock (an average score of $35.8 \%$ ). Sustainable poverty reduction can only be achieved and managed effectively if people's vulnerability is reduced (Agbaje et al., 2013). The respondents' poverty severity and possibility of falling into poverty is greatly affected by their vulnerability. This is because increased exposure to risk/ shocks reduces household ability to accumulate assets and income which can be invested in other key household needs like health and education.

\section{Multidimensional poverty status of households sampled}

Based on the magnitude of respondents' deprivations across the various indicators of poverty measurement used in the study, the result indicated that multidimensional poverty is pervasive among majority of the households in the study area. This finding lends credence to the submissions of OPHI (2017) and Tashikalma et al. (2016) who were of the view that poverty remained
Table 3. Multidimensional poverty status of the respondents

\begin{tabular}{lcc}
\hline \multicolumn{1}{r}{ Status } & Frequency & Percentage (\%) \\
\hline Poor & 296 & 61.7 \\
Non-poor & 184 & 38.3 \\
Total & 480 & 100.0 \\
\hline
\end{tabular}

Source: field survey, 2018.

a huge developmental challenge affecting Adamawa State.

\section{Factors influencing multidimensional poverty}

The result of the binary logit regression used to identify the determinants of multidimensional poverty in the study area is presented in Table 4. The logit model has 
a pseudo $\mathrm{R}^{2}$ of $60.2 \%$ and an LR statistic that is significant at $1 \%$, showing that the model is a good fit for the data. The result showed that the probability of being poor in the study area increases with advancement in age (and the coefficient is statistically significant at $1 \%$ ). This finding implies that the probability of being poor increases with age. The above is in consonance with the submissions of Adeoti (2014) and Amao et al. (2017) who reported that age is a significant determinant of poverty across Nigeria. In the study area, the likelihood of being poor increases with being a female (rather than male). This finding suggests that the study area exhibits poor equality between men and women in terms of accessing both economic and social resources. Also, marital status showed a significant influence on the households' poverty status in the study area. This finding suggests that the possibility of becoming multidimensionally poor is higher among married persons compared to their non-married counterparts. Similarly, the respondents' household sizes showed a significantly negative relationship with the likelihood of being non-poor in the study area. In line with the a priori expectation and the assertions of Adeoti (2014), multidimensional poverty reduces with an increase in the level of education of the household head. The study also revealed a direct positive relationship between the number of livelihood activities and the chances of being non-poor. This implies that respondents undertaking more activities are more likely to be non-poor compared to their counterparts with fewer activities. Further, the study revealed that farm size was also a significant factor affecting multidimensional poverty. This finding is in consonance with the result of Asogwa et al. (2012) who claimed that increased farm size improves the household's food security status. In this study, livestock ownership significantly affects the poverty status of the respondents. Also, remittance showed a significant relationship with poverty in the study area. The significance of remittance in this study could be attributed to the fact that access to remittance can contribute to improving household income which will likely be reflected in the household's wellbeing. This submission agrees with the views of Asogwa et al. (2012) and Adepoju and Adejere (2013) who reported that the probability of being poor is reduced by increased household access to remittance. In the same vein, access to credit also indicated a positive influence on the likelihood of being non-poor. This finding

Table 4. Parameter estimates for factors that influence multidimensional poverty

\begin{tabular}{lccc}
\hline \multicolumn{1}{c}{ Variable } & Coefficient & Std. error & $Z$-statistic \\
\hline Age $\left(X_{1}\right)$ & -0.039976 & 0.016103 & $-2.482527^{*}$ \\
Gender $\left(X_{2}\right)$ & 3.170254 & 0.781133 & $4.058531^{*}$ \\
Marital status $\left(X_{3}\right)$ & -2.879501 & 1.249619 & $-2.304304^{* *}$ \\
Household size $\left(X_{4}\right)$ & -0.353091 & 0.087364 & $-4.041599^{*}$ \\
Educational level $\left(X_{5}\right)$ & 0.159631 & 0.036763 & $4.342146^{*}$ \\
Livelihood activities $\left(X_{6}\right)$ & 0.656284 & 0.134820 & $4.867846^{*}$ \\
Farm size $\left(X_{7}\right)$ & 0.656954 & 0.129869 & $5.058577^{*}$ \\
Livestock ownership $\left(X_{8}\right)$ & $8.88 \mathrm{E}-06$ & $2.69 \mathrm{E}-06$ & $3.296863^{*}$ \\
Received remittance $\left(X_{9}\right)$ & $4.85 \mathrm{E}-06$ & $1.90 \mathrm{E}-06$ & $2.546460^{*}$ \\
Membership of group $\left(X_{10}\right)$ & 2.381698 & 0.351327 & $6.779154^{*}$ \\
Access to credit $\left(X_{11}\right)$ & 1.103260 & 0.352759 & $3.127516^{*}$ \\
Constant & -3.269280 & 1.799251 & $-1.817023^{* * *}$ \\
\hline
\end{tabular}

$*, * *, * * *$ Significant at $1 \%, 5 \%$ and $10 \%$, respectively.

Source: Eviews 9 software. 
validates the submissions of Adepoju and Adejere (2013) who revealed that households with access to higher amount of credit have a lower probability of being poor.

\section{CONCLUSION AND RECOMMENDATION}

This study established that multidimensional poverty is pervasive in rural parts of Adamawa State, and this trend will continue to worsen unless concrete efforts are made towards ameliorating it. Prioritizing the reduction of multidimensional poverty will promote improved livelihoods for rural residents while supporting peace and stability in these areas. Based on the findings the study, the following recommendations were made:

- There is need for adequate investment in critical (physical) infrastructure that will encourage diverse economic activities in rural areas.

- Provision of adequate security for life and property will reduce household vulnerabilities to stress/shock which contributes immensely to the people's poverty in the study area.

- Farmers should be encouraged to form societies that will enhance their agricultural production knowledge while reducing resource access constraints.

\section{SOURCE OF FINANCING}

Personal.

\section{REFERENCES}

Abur, C. C., Eche, E., Torruam, J. T. (2013). Millennium Development Goals (MDGs) and Poverty Reduction in Nigeria. Int. J. Basic App. Sci., 1(3), 504-510.

Adamawa State Government (2016). About Adamawa State. Retrieved March $8^{\text {th }} 2016$ from: www.adamawastate. gov.ng

Adeoti, A. I. (2014). Trend and determinants of multidimensional poverty in rural Nigeria. J. Dev. Agric. Econ., 6(5), 220-231.

Adepoju, A. O., Yusuf, S. A. (2012). Poverty and Vulnerability in Rural South-West Nigeria. ARPN J. Agric. Biol. Sci., $7(6), 430-437$.

Adepoju, A. O., Adejere, A. K. (2013). Food insecurity status of rural households during the post-planting season in $\mathrm{Ni}$ geria. J. Agric. Sust., 4(1), 16-35.

Aderonmu, J. A. (2010). Local Government and Poverty Eradication in Rural Nigeria. Canad. Soc. Sci., 6(5), 200-208.
Agbaje, M. A., Okunmadewa, F. Y., Omomona, B. T., Oni, O. A. (2013). An Assessment of Vulnerability to Poverty in Rural Nigeria. ARPN J. Agric. Biol. Sci., 8(1), 60-75.

Amao, J. O., Ayantoye, K., Fanifosi, G. E. (2017). An analysis of multidimensional poverty and its determinants in rural Nigeria. J. Dev. Agric. Econ., 9(11), 303-311.

Anacka, M., Kobus, M. (2011). Multidimensional Poverty Analysis in Polish Gminas. Faculty of Economic Sciences, Working Papers No. 23/2011 (63). Warsaw: University of Warsaw.

Asogwa, B. C., Okwoche, V. A., Umeh, J. C. (2012). Analysing the Determinants of Poverty Severity among Rural Farmers in Nigeria: A Censored Regression Model Approach. Am. Int. J. Contem. Res., 2(5), 166-176.

Battiston, D., Cruces, G., Calva, F. L., Lugo, M. A., Santos, M. E. (2013). Income and Beyond: Multidimensional Poverty in Six Latin American countries. Cos. Ind. Res., 112(2), 291-314

Bene, C., Friend, R. M. (2009). Water, Poverty and Inland Fisheries: Lessons from Africa and Asia. Cairo: World Fish Center.

Bieńkuńska, A. (2013). Multidimensional poverty and social isolation in Poland. Working paper 20. United Nations Economic Commission for Europe Conference of European Statisticians.

Cohen, A. (2009). The Multidimensional Poverty Assessment Tool: Design, development and application of a new framework for measuring rural poverty. Rome: IFAD.

Dudek, H., Lisicka, I. (2015). Determinants of poverty - binary logit model with interaction terms approach. Retrieved on Sep $2^{\text {nd }} 2019$ from: https://www.researchgate. net/publication/270285045

Egwemi, V., Odo, L. U. (2013). Rural Development and Poverty Eradication in Nigeria. JORIND, 11(1), 101-110.

Holmes, R., Akinrimisi, B., Morgan, J., Buck, R. (2012). Social Protection in Nigeria - Mapping programmes and their Effectiveness. London: Overseas Development Institute.

Ifelunini, I., Jonah, T. A., Wosowei, E. C., Otene, S. (2013). Multidimensional Poverty Incidence in Nigeria: Empirical Insight from Core Welfare Indicator Questionnaire (CWIQ) Survey. J. Econ. Sust. Dev., 14(6), 105-112.

IFAD (International Fund for Agricultural Development) (2014). The Multidimensional Poverty Assessment Tool: User's Guide. Rome, Italy: IFAD. Retrieved from www. ifad.org/mpat

Jana, S., Nad'a, B., Jana, T. (2012). Material Deprivation in Selected EU Countries According to EU-SILC Income Statistics. J. Compet., 4(2), 145-160.

Kalinowski, S. (2018). The Working Poor In The European Union. International Scientific Days 2018. Retrieved on Sep $2^{\text {nd }} 2019$ from: https://doi.org/10.15414/isd2018.s4.08 
Kanasz, T. (2017). The mass media and the question of poverty in Poland. Institute of Slavic Studies, Polish Academy of Sciences \& The Slavic Foundation. Retrieved from: https://ispan.waw.pl/journals/index.php/adeptus/article/ view/a.1509

Le, H. (2015). Multidimensional Poverty : Evidence from Vietnam. Econ. Bull., 35(4), 2820-2831.

Łuczka-Bakuła, W., Kalinowski, S. (2006). Poverty and its selected causes in the new EU countries. EJPAU, 9(1). Retrieved from: http://www.ejpau.media.pl/volume9/issue1/ abs-24.html

Margwa, R. S., Onu, J. I., Jalo, J. N., Dire, B. (2015). Analysis of poverty level among rural households in Mubi region of Adamawa State, Nigeria. J. Sci. Res. Stud., 2(1), 29-35.

Mitchell, T., Sabates-Wheeler, R., Devereux, S., Tanner, T., Davies, M., Leavy, J. (2008). Rural Disaster Risk-Poverty Interface. Brighton: Institute of Development Studies.

Muhammad, M. (2012). Poverty and National Security: A Review of Policies 1960-2010. JORIND, 10(2), 243-251. Retrieved from: www.transcampus.org./journals, www. ajol.info/journals/jorind

NBS (National Bureau of Statistics). (2012). Social and Economic Statistics in Nigeria. Abuja, Nigeria. Retrieved from: www.nbs.gov.ng

NBS (National Bureau of Statistics). (2017). Data Monitor. Abuja, Nigeria: NBS. Retrieved from: www.nbs.gov.ng

Ogbozor, E. (2016). Households in Conflict Network: Causes and Consequence of Violent Extremism in Northeast Nigeria. Brighton, UK. Retrieved from: www.hicn.org

Ologbon, O. A. C., Idowu, A. O., Oyebanjo, O., Akerele, E. O. (2014). Multidimensional Poverty Characteristics among Riverine Households in Southwestern Nigeria. J. Sust. Dev. Africa, 16(6), 126-144.

Onwuemele, A. (2015). Escalating Poverty in Nigeria: Appraising Institutional Frameworks for Poverty Reduction in Nigeria. Int. J. Econ. Dev. Res. Inv., 6(1), 1-21.
OPHI (Oxford Poverty and Human Development Initiative). (2017). OPHI Country Briefing For Nigeria, June 2017. Oxford Department of International Development, Queen Elizabeth House. Oxford: University of Oxford.

OPHI (Oxford Poverty and Human Development Initiative). (2018). Global Multidimensional Poverty Index 2018: The Most Detailed Picture to Date of the World's Poorest People. Oxford: University of Oxford.

Sokołowski, J., Lewandowski, P., Kiełczewska, A., Bouzarovski, S. (2019). Measuring Energy Poverty in Poland With the Multidimensional Energy Poverty Index. IBS Working Paper 07/2019.

Tashikalma, A. K., Aletogbe, B. C., Michael, A. (2016). Analysis of Poverty Level among Some Selected Households in Girei Local Government Area of Adamawa State, Nigeria. Sci. Paper. Ser. Manag. Econ. Eng. Agric. Rural Dev., 16(3), 345-352.

Tollens, E. (2002). The Challenges of Poverty Reduction with Particular Reference to Rural Poverty and Agriculture in Sub-Saharan Africa (No. 2002/67). Belgium.

UNDP (2018). National Human Development Report 2018. Achieving Human Development in North-East Nigeria. Plot 617/618 Diplomatic Drive, Central Area District, Diplomatic Zone, Garki, Abuja FCT, Nigeria.

USAID (United State Agency For International Development) (2015). Nigeria Development. Abuja, Nigeria.

World Poverty Clock (2018). Nigeria Poverty Index. Retrieved Dec $20^{\text {th }} 2018$ from: https://www.worldpoverty.io/ index

Yang, L., Vizard, P. (2017). Multidimensional poverty and income inequality in the EU. The London School of Economics and Political Science, Centre for Analysis of Social Exclusion CASEpaper 207/LIPpaper 4. 